\title{
Seasonal variations in phytoplankton diversity in the Bui dam area of the Black Volta in Ghana during the pre- and post-impoundment periods
}

\author{
Elliot Haruna Alhassan \\ Department of Fisheries \& Aquatic Resources Management, University for Development Studies, P. O. Box TL 1882. \\ Tamale, Ghana; ehalhassan@gmail.com
}

\author{
Received 29-IV-2014. Corrected 30-IX-2014. Accepted 29-X-2014.
}

\begin{abstract}
Phytoplankton constitutes the primary producers of aquatic ecosystems and represents the food chain base that supports the commercial fisheries of most water bodies. Nowadays, there is lack of information on phytoplankton assemblages of most reservoirs in Africa. To contribute with this knowledge, this study was carried out to determine the density and diversity of seasonal variations of phytoplankton species in the Bui dam area of the Black Volta, during the pre- (2011) and post-impoundment (2012) periods. For this, a three-level stratified random sampling approach was adopted for 22 months. Phytoplankton samples were obtained by towing a $0.5 \mathrm{~m}$ diameter phytoplankton net $\left(35 \mu \mathrm{m}\right.$ mesh size and $0.25 \mathrm{~m}^{2}$ mouth surface area) from a non-motorized canoe through a distance of about $100 \mathrm{~m}$ against the current from downstream to upstream of the river. In 2011, 35 species of phytoplankton belonging to four classes, Bacillariophyceae (7.6\%), Chlorophyceae (43\%), Cyanophyceae (48.6\%) and Euglenophyceae (0.8\%) were identified. In the 2012 sampling, 18 species belonging to three classes, Bacillariophyceae (2.2\%), Chlorophyceae $(26.1 \%)$ and Cyanophyceae $(71.7 \%)$ were observed. A total of 17 species of phytoplankton, including Gyrosigma sp., Surirella sp., Carteria sp., Chlosterium sp., Chlorogonium sp., Coelastrum sp., Cosmarium sp., Volvox sp., Chroococcus sp., Coelosphaerium sp., Rivularia sp. and Spirulina sp., were absent during the late post-impoundment period. Mean monthly total phytoplankton abundance decreased from June (7 384 cells $\left./ \mathrm{m}^{3}\right)$ to August $\left(106\right.$ cells $\left./ \mathrm{m}^{3}\right)$ in 2011. In 2012 however, mean total phytoplankton decreased from February $\left(1237 \mathrm{cells} / \mathrm{m}^{3}\right)$ to August $\left(4 \mathrm{cell} / \mathrm{s} / \mathrm{m}^{3}\right)$. The results also showed that variations occurred between seasons among some phytoplankton groups. The dry and pre-wet seasons had significantly $(\mathrm{p}<0.05)$ higher mean phytoplankton abundance than the wet season during the 22 months of sampling period. The biotic indices of Shannon-Wiener $\left(\mathrm{H}^{1}\right)$ were homogenously distributed in the four hydrological seasons of the two years. The phytoplankton groups, Bacillariophyceae, Chlorophyceae, Euglenophyceae and total phytoplankton differed significantly $(\mathrm{p}<0.05)$ between the pre- and post-impoundment periods. The total phytoplankton was also significantly $(\mathrm{p}<0.05)$ higher in the upstream station than the downstream station indicating the impact of the impoundment on the downstream ecology. Hence, river management strategies should be implemented by hydro-biologist to lessen the impact of the dam on the downstream ecology. Rev. Biol. Trop. 63 (1): 13-22. Epub 2015 March 01.
\end{abstract}

Key words: impoundment, chlorophyceae, cyanophyceae, seasonal density, downstream station.

The creation of dams is known to be implicated in negative human impacts on river ecosystems as they modify physical environment and regulate flow (Allan, 1996). According to Junk, Bayley and Sparks (1989), dams interrupt stream flow and generate hydrological changes along the integrated continuum of river ecosystems that ultimately reflect in the fisheries and hydro-biology of rivers. The most obvious effects of placing dams on rivers result from the formation of new lentic environments upstream from the dam and tail water environment downstream of the dam (FAO, 2001). Cumulative effects of dams in catchment basins and tributary streams can significantly block nutrient flow, affecting plankton in river channels (Hess, Schlesinger, Hergenrader, Reetz \& Lewis, 1982). 
Despite these negative impacts, the number of damming projects worldwide keeps increasing purposely for the generation of hydroelectric power, irrigation and flood control. The Government of Ghana is contributing to the global increase in dams by creating another dam at the Bui gorge on the Black Volta in addition to the existing Akosombo and Kpong dams for the generation of hydroelectric power. The Bui dam will create a reservoir covering an area of about $444 \mathrm{~km}^{2}$ at full supply level (FSL) of 183 meters above sea level (masl) and holding about 12600 million $\mathrm{m}^{3}$ of water which will be used for the generation of electricity. Most of the reservoir area will be contained within the nearby Bui National Park. The dam created by the Bui barrage is expected to impact through inundation, the assemblages of fishes, plankton and macro-benthic fauna.

Communities inhabiting the dam can be classified based on their position in the energy level: producers; consumers and decomposers (Visser, 1970). Primary production by algae in the water sets the level of food available for secondary producers such as zooplankton and fish. When nutrient availability is high, overall production varies with water temperature (Hewett, \& Johnson, 1987). It is likely that rates of primary production will be altered by climate change and may result in significant consequences for aquatic ecosystems and the human communities that use them. Decreases in primary production on the one hand, will reduce food availability at the bottom of the food web; ultimately causing reductions in productivity of fish at the top of the food web while on the other, excessive increases in primary production will produce eutrophic conditions, exemplified by degraded water quality and noxious blue green algal blooms.

Differences in the water temperature, transparency and nutrient level produces changes in the phytoplankton composition (Tundisi, 1993), which can be seen up to $350 \mathrm{~km}$ downstream from the Yacyreta dam in Argentina (Petts, 1984). The whole algal fauna of the Volga
River was modified after the conversion of the river into a cascade of reservoirs (MordukhaiBoltovskoi, 1979). The phytoplankton of the Dniester River likewise underwent qualitative and quantitative changes after the closure of the Dubassery reservoir with increases in Cyanophyceae downstream of the dam. The phytoplankton biomass varied between $0.66-0.85 \mathrm{~g} /$ $\mathrm{m}^{3}$ before the dam was built but rose to $4 \mathrm{~g} / \mathrm{m}^{3}$ after its construction (Welcomme, 1985). In the Nile River at the Gebel Aulia dam, the dam slowed the Nile current and produced a rapid increase in phytoplankton concentration. When the dam was opened, the flow was faster and phytoplankton concentration dropped, hence demonstrated a strong correlation between phytoplankton and current velocity in the river (Prowse, \& Talling, 1958). According to Rzoska and Talling (1966), phytoplankton was more abundant in the backwaters of the Nile Sudd than in the main channels, thus Rzoska (1974) obtained values of between 40 and 140cells/ $\mathrm{mL}$ for the river, whereas densities in lagoons were between 1720 and 2330 cells/mL. In the Tagwai Dam in Nigeria, phytoplankton species diversity showed that Cyanophyceae had three genera, Bacillariophyceae (10), Desmidiaceae (3) and Chlorophyceae (15) (Kolo, Ojutiku, \& Musulmi, 2010).

Soon after the creation of the Volta Lake in Ghana as a result of the construction of the Akosombo dam, Blue-green algae dominated the phytoplankton population increasingly towards the extremities of the Lake arms where the water column was both shallower and more sheltered from turbulence by wind (Viner, 1970). It is anticipated that similar changes in the density and diversity of phytoplankton of the Black Volta would take place soon after the creation of the Bui dam. The present study has, therefore its specific value, for assessing the phytoplankton species abundance and diversity of the Black Volta in the Bui dam area during the pre- and post-impoundment periods. This will generate information on the floral characteristics in both periods of river impoundment. 


\section{MATERIALS AND METHODS}

Study site: The study was carried out for 22 months (March 2011-December 2012) on the Bui dam section of the Black Volta in Ghana. The study area stretched from the Bui reservoir (upstream) to Bamboi (downstream) within $8^{\circ} 09^{\prime}-8^{\circ} 16^{\prime} \mathrm{N}-2^{\circ} 01^{\prime}-2^{\circ} 15^{\prime} \mathrm{W}$ and a distance of about $37.5 \mathrm{~km}$. The Bui dam will create a reservoir covering an area of about $444 \mathrm{~km}^{2}$ at full supply level (FSL) (at 183masl) and holding about 12600 million $\mathrm{m}^{3}$ of water which will be used for the generation of electricity and reservoir volume at FSL $\left(\mathrm{m}^{3}\right)$ of $12.57 \times 10^{9}$. There is considerable variation in local relief of the Black Volta basin. The Northern areas ranged from 300-600masl. The Basin is gently undulating from the North to the South. Most part of the Black Volta falls under the Savanna zone which is undulating with gentle slopes that promotes overland flow. The low relief is also a cause for the poor surface drainage with a consequent flooding which characterize the desertification-prone areas during the wet season (Agorsah, 2004).

Sampling design: In order to provide an all-year picture of the hydro-biology of the study area, a three-level stratified random sampling approach was adopted. The first stratum, defined by the four designated hydrological seasons in the study area, was referred to as follows: dry season (January to March); prewet season (April to June); wet season (July to September); and post-wet season (October to December) (Abban, Kwarfo-Apegyah, \& Amedome, 2000). The second stratum, defined by the three impoundment periods in the study area, was referred to as: pre-impoundment (March to May 2011); immediate postimpoundment (June to December 2011); and late post-impoundment (January to December 2012). The third stratum was related to the sampling stations as follows: above the dam site or reservoir area with sampling station at Bui (old town currently submerged); and below the dam site area with sampling station at Bamboi.
Collection and enumeration of phytoplankton samples: Triplicate phytoplankton samples were collected monthly for 22 months (March 2011-December 2012) between 0600 and 0700 GMT from each of the two sampling sites. The samples were obtained by towing a $0.5 \mathrm{~m}$ diameter phytoplankton net $(35 \mu \mathrm{m}$ mesh size and $0.25 \mathrm{~m}^{2}$ mouth surface area) from a nonmotorized canoe through a distance of about $100 \mathrm{~m}$ against the current from downstream to upstream. The phytoplankton samples were preserved with $1 \%$ Lugol solution in $50 \mathrm{~mL}$ sampling bottles.

For enumeration of algal taxa, the description by Lund, Kipling and le Cren (1958) was adopted using a Carl Zeiss Axiovert S100 inverted microscope. The species identification was done following Needham and Needham (1962). The water samples were well shaken and aliquots of $15 \mathrm{~mL}$ were transferred into counting chambers for microscopic study. Sedimentation was carried out in counting chambers with a settling time of four hours for every $1 \mathrm{~cm}$ of water column of the sample, as described by Wetzel and Likens (1990). The phytoplankton densities were expressed as cells $/ \mathrm{m}^{3}$ from the average count of three aliquots of $5 \mathrm{~mL}$ each. For the filamentous algae, the average cell length was determined to be $4.8 \pm 0.34 \mu \mathrm{m}$. Hence, for calculation of total cell counts, average cell length was assumed to be $5 \mu \mathrm{m}$. Therefore, cell densities were estimated by dividing the determined cell count $\left(\mathrm{C}_{\text {total }}\right)$ through the filtered sample volume and expressed as cell counts $/ \mathrm{m}^{3}$.

The plankton abundance of the four hydrological seasons were analysed using one way analysis of variance (ANOVA) of SPSS v. 16 on $\log (\mathrm{x}+1)$ transformed data. Where there were significant differences $(\mathrm{p}<0.05)$ among means, the Duncan multiple range test was used to compare the treatment means.

The data on diversity of phytoplankton during each hydrological season were calculated with the data from plankton abundance by number using the PRIMER software version 6.1.6 (Clarke, \& Gorley, 2006). Species diversity was estimated using the Shannon-Wiener 
index $\left(\mathrm{H}^{1}\right)$ (Shannon \& Weaver, 1963) from the density data (bits/ind.) and was expressed as:

$$
\mathrm{H}^{1}=- \text { - pi } \log \mathrm{Pi},
$$

where $\mathrm{Pi}$ is the proportion of individuals in the $\mathrm{i}^{\text {th }}$ species (Dahlberg, \& Odum, 1970).

\section{RESULTS}

Phytoplankton composition, density and diversity: Table 1 shows a checklist of phytoplankton species during the pre- and postimpoundment periods while Fig. 1A and Fig. $1 \mathrm{~B}$ shows the species composition and abundance in 2011 and 2012. In 2011, 35 species of phytoplankton belonging to four classes Bacillariophyceae (7.6\%), Chlorophyceae (43\%),
Cyanophyceae 48.6\%) and Euglenophyceae $(0.8 \%)$ were identified, while in 2012,18 species belonging to three classes Bacillariophyceae $(2.2 \%)$, Chlorophyceae $(26.1 \%)$ and Cyanophyceae $(71.7 \%)$ were identified (Fig. 2 ). Phytoplankton species diversity was lowest $(0.8863)$ in the post-wet season and highest (1.2465) in the pre-wet season in 2011; while in 2012 , diversity was lowest (0.9806) in the dry season, and highest (1.0583) in the post-wet season (Fig. 3).

Class Bacillariophyceae: Four species of Bacillariophyceae were identified in 2011 and two species in 2012 with Synedra ulna being the dominant species in both years. The mean seasonal variations in Bacillariophyceae during 2011 decreased from $171.7 \mathrm{cells} / \mathrm{m}^{3}$ in

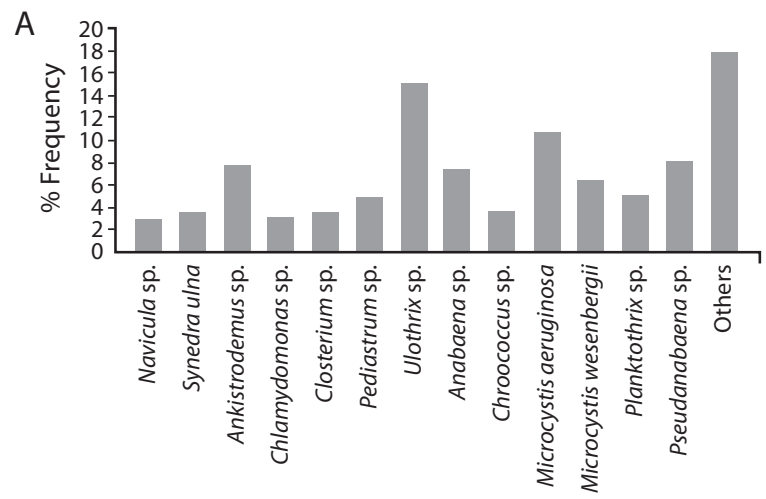

Phytoplankton species

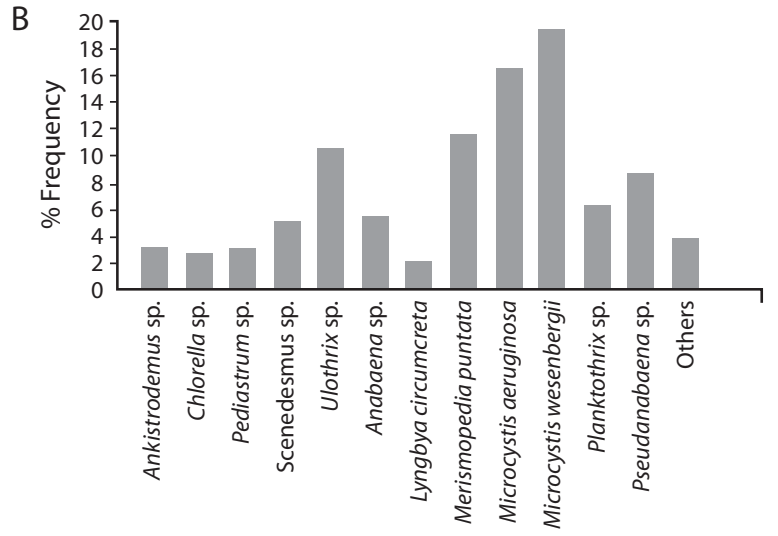

Phytoplankton species

Fig. 1. A) Phytoplankton species composition in the Bui dam area of the Black Volta in 2011.

Fig. 1. B) Phytoplankton species compositionin the Bui dam area of the Black Volta in 2012. 
TABLE 1

Checklist of phytoplankton species during the pre- and post-impoundment periods

\begin{tabular}{|c|c|c|c|}
\hline Class/species & $\begin{array}{l}\text { Pre-impoundment } \\
\text { (Mar-May 2011) }\end{array}$ & $\begin{array}{l}\text { Immediate post-impoundment } \\
\text { (Jun-Dec 2011) }\end{array}$ & $\begin{array}{l}\text { Late post-impoundment } \\
\text { (Jan-Dec 2012) }\end{array}$ \\
\hline \multicolumn{4}{|l|}{ Bacillariophyceae } \\
\hline Gyrosigma sp. & + & + & - \\
\hline Navicula sp. & + & + & + \\
\hline Surirella sp. & + & - & - \\
\hline Synedra ulna & + & + & + \\
\hline \multicolumn{4}{|l|}{ Chlorophyceae } \\
\hline Ankistrodesmus sp. & + & + & + \\
\hline Carteria $\mathrm{sp}$ & + & - & - \\
\hline Chlamydomonas sp. & + & - & + \\
\hline Chlorella $\mathrm{sp}$. & + & + & + \\
\hline Chlorogonium sp. & + & - & - \\
\hline Closterium sp. & + & - & - \\
\hline Coelastrum sp. & + & + & - \\
\hline Cosmarium sp. & + & - & - \\
\hline Dictyosphaerium sp. & + & - & - \\
\hline Micrasterias sp. & + & - & + \\
\hline Pediastrum sp. & + & - & + \\
\hline Scenedesmus sp. & + & + & + \\
\hline Schroederia sp. & + & - & - \\
\hline Staurastrum sp. & + & - & + \\
\hline Stigeoclonium sp. & + & - & - \\
\hline Ulothrix sp. & + & + & + \\
\hline Volvox sp. & - & + & - \\
\hline \multicolumn{4}{|l|}{ Cyanophyceae } \\
\hline Anabaena sp. & + & + & + \\
\hline Chroococcus sp. & + & - & - \\
\hline Coelosphaerium sp. & + & - & - \\
\hline Lyngbya circumcreta & + & + & + \\
\hline Merismopedia puntata & - & + & + \\
\hline Microcystis aeruginosa & + & + & + \\
\hline Microcystis wesenbergii & - & + & + \\
\hline Oscillatoria sp. & + & + & + \\
\hline Planktothrix sp. & + & + & + \\
\hline Pseudoanabaena sp. & + & + & + \\
\hline Rivularia sp. & + & - & - \\
\hline Spirulina sp. & + & - & - \\
\hline \multicolumn{4}{|l|}{ Euglenophyceae } \\
\hline Euglena sp. & + & - & - \\
\hline Phacus pyrum & + & - & - \\
\hline
\end{tabular}

Key: + means present; - indicates absent.

the dry season to $1.7 \mathrm{cells} / \mathrm{m}^{3}$ in the post-wet season with a significant difference $(p<0.05)$ between the pre-wet and wet seasons (Table 2). Bacillariophyceae densities decreased from $27.3 \mathrm{cells} / \mathrm{m}^{3}$ in the pre-wet season to $4.67 \mathrm{cells} / \mathrm{m}^{3}$ in the wet season with significant differences $(\mathrm{p}<0.05)$ between the pre-wet season and the three other hydrological seasons in 2012 (Table 3). There was no significant difference $(p>0.05)$ between the upstream and downstream stations in 2011. There was however, a significant difference $(\mathrm{p}<0.05)$ between 


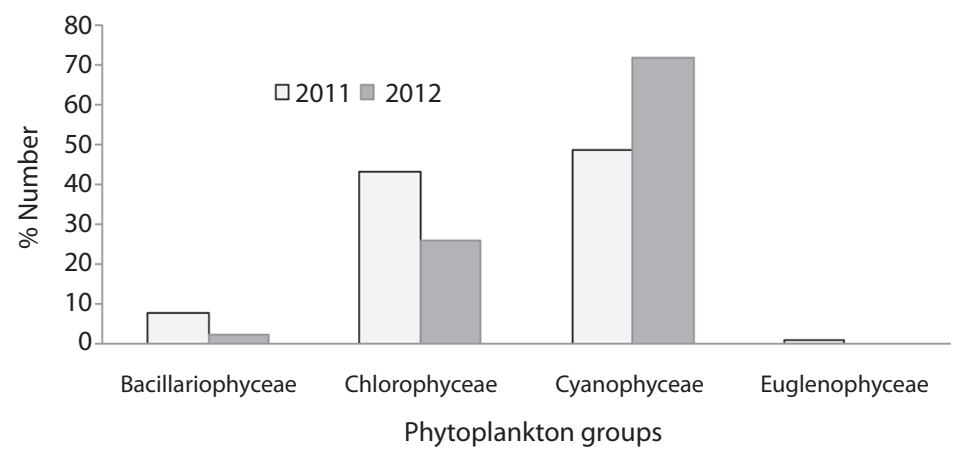

Fig. 2. Composition of phytoplankton groups in the Bui dam area of the Black Volta in 2011 and 2012.

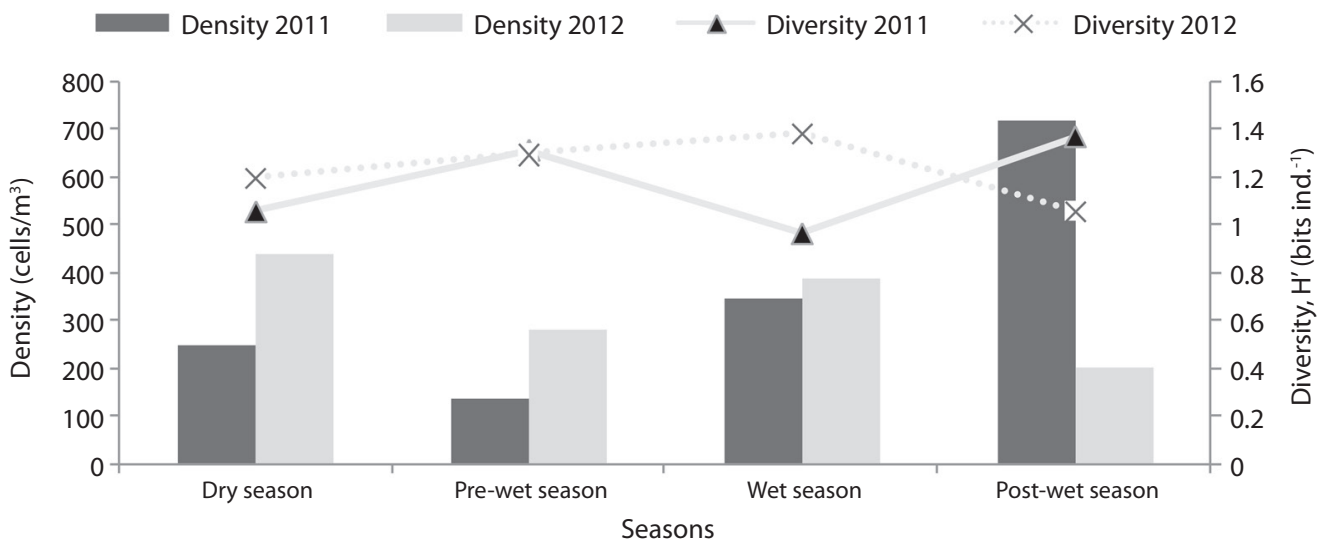

Fig. 3. Seasonal variations in density and diversity of phytoplankton in the Bui dam area of the Black Volta in 2011 and 2012.

TABLE 2

Seasonality of mean phytoplankton classes in 2011 (mean \pm standard error)

\begin{tabular}{lcccc}
\multicolumn{1}{c}{ Taxa $\left(\right.$ cells $\left./ \mathrm{m}^{3}\right)$} & Dry season & Pre-wet season & Wet season & Post-wet season \\
Bacillariophyceae & $171.7^{\mathrm{ab}} \pm 6.1$ & $357.7^{\mathrm{a}} \pm 15.0$ & $8.0^{\mathrm{b}} \pm 0.6$ & $1.7^{\mathrm{b}} \pm 0.2$ \\
Chlorophyceae & $1119.3^{\mathrm{ab}_{2}}+24.9$ & $1983.0^{\mathrm{a}} \pm 45.7$ & $8.0^{\mathrm{c}} \pm 0.5$ & $244.0^{\mathrm{bc}} \pm 20.2$ \\
Cyanophyceae & $194.0^{\mathrm{a}_{2}} \pm 2.5$ & $1907.3^{\mathrm{b}} \pm 10.9$ & $274.3^{\mathrm{a}} \pm 2.9$ & $641.0^{\mathrm{a}} \pm 29.0$ \\
Euglenophyceae & - & $53.3 \pm 2.7$ & - & - \\
Total phytoplankton & $1414.3^{\mathrm{ab}_{ \pm}}$ & $3906.0^{\mathrm{a}} \pm 19.6$ & $290.3^{\mathrm{b}} \pm 12.5$ & $886.7^{\mathrm{a}_{ \pm}} \pm 48.8$ \\
\hline
\end{tabular}

Figs on the same row with different superscript letters are significantly different $(\mathrm{p}<0.05)$ from one another.

the upstream and downstream stations in 2012. Additionally, mean densities of Bacillariophyceae decreased from 268 cells $/ \mathrm{m}^{3}$ during the pre-impoundment period to 11.08 cells/ $\mathrm{m}^{3}$ during the late post-impoundment period with significant difference $(\mathrm{p}<0.05)$ (Table 4). Hence, the abundance of phytoplankton species belonging to the class Bacillariophyceae changed following the impoundment of the Black Volta by the Bui dam. 
TABLE 3

Seasonality of mean phytoplankton classes in 2012 (mean \pm standard error)

\begin{tabular}{lcccc}
\multicolumn{1}{c}{ Taxa $\left(\right.$ cells $\left./ \mathrm{m}^{3}\right)$} & Dry season & Pre-wet season & Wet season & Post-wet season \\
Bacillariophyceae & $6.0^{\mathrm{a}} \pm 0.4$ & $27.3^{\mathrm{a}} \pm 0.9$ & $4.7^{\mathrm{a}} \pm 0.7$ & $6.3^{\mathrm{a}} \pm 1.5$ \\
Chlorophyceae & $194.7^{\mathrm{a}} \pm 8.2$ & $246.0^{\mathrm{a}} \pm 4.6$ & $62.0^{\mathrm{b}} \pm 3.5$ & $56.7^{\mathrm{b}} \pm 19.0$ \\
Cyanophyceae & $696.0^{\mathrm{a}} \pm 15.3$ & $533.0^{\mathrm{a}}{ }^{\mathrm{a}} \pm 21.2$ & $117.0^{\mathrm{b}} \pm 7.4$ & $94.7^{\mathrm{b}} \pm 12.7$ \\
Total phytoplankton & $897.7^{\mathrm{a}} \pm 18.2$ & $806.3^{\mathrm{a}} \pm 26.3$ & $183.7^{\mathrm{b}} \pm 11.3$ & $157.7^{\mathrm{b}} \pm 32.6$ \\
\hline
\end{tabular}

Figs on the same row with different superscript letters are significantly different $(p<0.05)$ from one another.

TABLE 4

Mean phytoplankton classes during the pre- and post-impoundment periods (mean \pm standard error)

\begin{tabular}{lcccc} 
Taxa (cells $\left./ \mathrm{m}^{3}\right)$ & $\begin{array}{c}\text { Pre-impoundment } \\
\text { (Mar-May 2011) }\end{array}$ & $\begin{array}{c}\text { Immediate } \\
\text { post-impoundment } \\
\text { (June-Dec 2011) }\end{array}$ & $\begin{array}{c}\text { Late } \\
\text { post-impoundment } \\
(\text { Jan-Dec 2012) }\end{array}$ & $P$ value \\
Bacillariophyceae & $268.0^{\mathrm{a}} \pm 12.6$ & $78.4^{\mathrm{b}} \pm 7.4$ & $11.1^{\mathrm{b}} \pm 3.7$ & $0.02^{*}$ \\
Chlorophyceae & $108.2^{\mathrm{a}} \pm 46.8$ & $518.4^{\mathrm{b}} \pm 40.2$ & $139.8^{\mathrm{a}} \pm 33.1$ & 0.09 \\
Cyanophyceae & $654.3^{\mathrm{a}} \pm 39.3$ & $962.4^{\mathrm{a}} \pm 52.3$ & $360.2^{\mathrm{a}} \pm 97.7$ & 0.35 \\
Euglenophyceae & $53.3^{2} \pm 2.7$ & - & - & $0.00^{*}$ \\
Total phytoplankton & $2057.7^{\mathrm{b}} \pm 91.2$ & $1559.3^{\mathrm{a}} \pm 99.6$ & $511.1^{\mathrm{a}} \pm 26.1$ & 0.22 \\
\hline
\end{tabular}

*On the P values indicates significant differences $(\mathrm{p}<0.05)$; Figs on the same row with different superscript letters are also significantly different $(\mathrm{p}<0.05)$ from one another.

Class Chlorophyceae: A total of 17 and eight species of Chlorophyceae were identified in 2011 and 2012, respectively, with Ulothrix sp. as the most dominant. The mean seasonal variations in Chlorophyceae densities during 2011 decreased from 1983 cells $/ \mathrm{m}^{3}$ in the prewet season to 8 cells $/ \mathrm{m}^{3}$ in the wet season with a significant difference $(\mathrm{p}<0.05)$. Chlorophyceae densities decreased from 246 cells $/ \mathrm{m}^{3}$ in the pre-wet season to $56.7 \mathrm{cells} / \mathrm{m}^{3}$ in the post-wet season in 2012. There were significant differences $(p<0.05)$ between the pre-wet, wet and post-wet seasons. There was no significant difference $(p>0.05)$ between the upstream and downstream stations in 2011. There was however, a significant difference $(\mathrm{p}<0.05)$ in the densities of species of Chlorophyceae between the upstream and downstream stations in 2012. Besides, mean densities of Chlorophyceae increased from 108.2 cells $/ \mathrm{m}^{3}$ during the pre-impoundment period to $518.43 \mathrm{cells} /$ $\mathrm{m}^{3}$ in the immediate post-impoundment period. There was a significant difference $(p<0.05)$ between the pre-impoundment and late postimpoundment periods. Hence, the the abundance of phytoplankton species belonging to the class Chlorophyceae changed following the impoundment of the Black Volta by the Bui dam.

Class Cyanophyceae: A total of 12 species of Cyanophyceae were recorded and the dominant species was Microcystis aeruginosa in 2011. In 2012, eight species were recorded with Microcystis wesenbergii being dominant. The mean seasonal variations in 2011 increased from $194 \mathrm{cells} / \mathrm{m}^{3}$ in the dry season to $1907.3 \mathrm{cells} / \mathrm{m}^{3}$ in the pre-wet season with a significant difference $(\mathrm{p}<0.05)$ between the pre-wet season and the other 3 seasons. During 2012, densities also increased from 94.7 cells $/ \mathrm{m}^{3}$ during the post-wet season to $696 \mathrm{cells} / \mathrm{m}^{3}$ in the dry season. There were significant differences $(p<0.05)$ between the dry and wet seasons. Cyanophyceae differed significantly $(p<0.05)$ between the upstream 
and downstream stations in both 2011 and 2012. Also, Cyanophyceae densities decreased from $962.43 \mathrm{cell} / \mathrm{s} / \mathrm{m}^{3}$ in the immediate postimpoundment period to $360.17 \mathrm{cells} / \mathrm{m}^{3}$ during the late post-impoundment period with no significant difference $(\mathrm{p}>0.05)$ among the periods. Hence, the abundance of phytoplankton species belonging to the class Cyanophyceae did not change following the impoundment of the Black Volta by the Bui dam.

Class Euglenophyceae: Two species of the class Euglenophyceae: Euglena sp. and Phacus pyrum were recorded in the 2011 sampling year. During 2012, no species was identified. The seasonal variations showed that species of the class Euglenophyceae were absent in the dry, wet and post-wet seasons, but present $\left(53.3\right.$ cells $\left./ \mathrm{m}^{3}\right)$ in the pre-wet season. This indicates that species of Euglenophyceae were only present during the pre-impoundment period of the study. Hence, the density of species of the class Euglenophyceae changed following the impoundment of the Black Volta by the Bui dam.

\section{DISCUSSION}

A total of 35 species of phytoplankton belonging to four classes were recorded during the study. The number of species per class were dominated by Chlorophyceae (17 species), Cyanophyceae (12 species), Bacillariophyceae (4 species), and Euglenophyceae (2 species). The distribution pattern of phytoplankton during the study showed that all the species, except Euglena sp. and Phacus pyrum (Euglenophyceae) were homogenously distributed in the four hydrological seasons. The lotic nature of the study area may be responsible for the relatively uniform seasonal distribution. Zabbey, Sikoki and Edoghotu (2008) reported that in lotic ecosystems, continuous flows ensure near uniform distribution of organisms. The impoundment of the Black Volta may, however, be the principal factor responsible for the discontinuous seasonal distribution of Euglena sp. and Phacus pyrum observed in the study.
In all, 17 species of phytoplankton, including Gyrosigma sp., Surirella sp., Carteria sp., Closterium sp., Chlorogonium sp., Coelastrum sp., Cosmarium sp., Volvox sp., Chroococcus sp., Coelosphaerium sp., Rivularia sp. and Spirulina sp. were absent during the late postimpoundment period. Their absence indicates that they could possibly not be adaptable to the impoundment-induced environmental changes due to their preference for lotic water bodies. This therefore indicated that river impoundment had impact on the density and distribution of these species in the study area. Hence preimpoundment studies should always be carried out when impounding a river to identify the phytoplankton species that may be altered as a result of river impoundment.

The results also showed that variations occurred between seasons and in some phytoplankton groups. The dry and pre-wet seasons had significantly higher mean phytoplankton abundance than the wet season during the sampling period. Phytoplankton abundance is associated with seasonal differences in flow. Densities of phytoplankton usually reach the peak in the dry season and diminish in the floods, unless otherwise influenced by temperature (Welcomme, 1985) or grazing effect of zooplankton (Rocha, Matsumura-Tundisi, Espindola, Roche, \& Rietzler, 1999). In the Kafue River in Zambia, phytoplankton densities were found to be less during the floods and dense blooms occurring when the floods had receded (Carey, 1971). Seasonal variations in phytoplankton abundance with higher values in the dry season have also been reported by Erondu and Chinda (1991), Ogamba, Chinda, Ekweozor and Onwuteaka (2004) and Emmanuel and Onyema (2007).

The biotic indices of Shannon-Wiener were homogenously distributed in the four hydrological seasons of the two years. Minimal variations in the diversity of phytoplankton as reflected by Shannon-Wiener $\left(\mathrm{H}^{1}\left(\log _{10}\right)\right.$, may be attributed to uniform physical and chemical conditions (Ogamba et al., 2004). According to Williams (1964), species diversity indices often reflect the impact of pollution on aquatic 
communities and pollution affects the distribution, standing crop and chlorophyll $a$ concentration of phytoplankton (Barnes, 1980). The species in this study area were distributed fairly in all four seasons. This therefore suggests that at present pollution has minimal effect on the Black Volta near the Bui dam. Thus the phytoplankton can support a good fishery, because phytoplankton are the major producers and a food source for plankton consumers (Wehr, \& Descy, 1998) and as well serve as the base of food chain that supports commercial fisheries (Conde, Bonita, Aubruit, Leon, $\&$ Pintos, 2007).

\section{ACKNOWLEDGMENTS}

The author is grateful to James Akomeah, a Technician of the Department of Marine and Fisheries Sciences of the University of Ghana, Legon for his input during the field work, and Ruth Amole, a Senior Technical Officer of the CSIR-Water Research Institute, Accra for her assistance in the laboratory work.

\section{RESUMEN}

Variaciones estacionales en la diversidad del fitoplancton en la zona de la represa Bui del Volta Negro, Ghana, durante los períodos pre y post-embalse. El fitoplancton constituye uno de los productos primarios de los ecosistemas acuáticos y representa la base de la cadena alimentaria que mantiene las pesquerías comerciales de la mayoría de los cuerpos de agua. Hoy en día, hay una falta de información sobre el fitoplancton de la mayoría de los embalses en África. Este estudio se llevó a cabo para determinar la densidad y diversidad de las variaciones estacionales de las especies de fitoplancton en la zona de la represa Bui del Volta Negro, durante los periodos pre (2011) y post embalse (2012). Para ello, se adoptó un método de muestreo aleatorio estratificado de tres niveles para 22 meses. Las muestras de fitoplancton fueron obtenidas desde una canoa sin motor a través de $100 \mathrm{~m}$ de distancia frente a la corriente de aguas abajo a aguas arriba del río, con una red de $0.5 \mathrm{~m}$ de diámetro $(35 \mu \mathrm{m}$ tamaño de malla y $0.25 \mathrm{~m}^{2}$ superficie de boca). En 2011, se identificaron 35 especies de fitoplancton pertenecientes a cuatro clases: Bacillariophyceae (7.6\%), Chlorophyceae (43\%), Cyanophyceae (48.6\%) y Euglenophyceae $(0.8 \%)$. En el muestreo de 2012 se observaron 18 especies pertenecientes a tres clases: Bacillariophyceae (2.2\%), Chlorophyceae (26.1\%) y Cyanophyceae (71.7\%). Un total de 17 especies de fitoplancton, incluidas Gyrosigma sp., Surirella sp., Carteria sp., Chlosterium sp., Chlorogonium sp., Coelastrum sp., Cosmarium sp., Volvox sp., Chroococcus sp., Coelosphaerium sp., Rivularia sp. y Spirulina sp., estuvieron ausentes durante el periodo post embalse. La media mensual de la abundancia total de fitoplancton disminuyó de junio (7 384 células $/ \mathrm{m}^{3}$ ) hasta agosto $\left(106\right.$ células $/ \mathrm{m}^{3}$ ) 2011. Sin embargo en 2012, la media del fitoplancton total disminuyó desde febrero (1 237cells $\left./ \mathrm{m}^{3}\right)$ a agosto $\left(4\right.$ cells $\left./ \mathrm{m}^{3}\right)$. Los resultados también mostraron que las variaciones se produjeron entre las temporadas entre algunos grupos de fitoplancton. Las estaciones secas y húmedas tuvieron significativamente $(p<0.05)$ mayor abundancia media de fitoplancton en la temporada de lluvias durante los 22 meses del periodo de muestreo. Los índices bióticos de Shannon-Wiener (H1) se distribuyeron de forma homogénea en las cuatro estaciones hidrológicas de los dos años. Los grupos de fitoplancton, Bacillariophyceae, Chlorophyceae, Euglenophyceae $\mathrm{y}$ fitoplancton total difirieron significativamente $(\mathrm{p}<0.05)$ entre los períodos pre y post-embalse. El fitoplancton total también fue significativamente $(\mathrm{p}<0.05)$ mayor en la estación aguas arriba que en la estación aguas abajo indicando el impacto del embalse sobre la ecología de aguas abajo. Por lo tanto, las estrategias de gestión de los ríos, debe ser ejecutada por un hidro-biólogo para disminuir el impacto de la represa en la ecología aguas abajo.

Palabras clave: embalse, chlorophyceae, cyanophyceae, densidad estacional, estación de aguas abajo.

\section{REFERENCES}

Abban, E. K., Kwarfo-Apegyah, K., \& Amedome, E. (2000). Annual report on fish monitoring in relation to Onchocerciasis control programme in the Volta Basin in Ghana. Accra, Ghana: CSIR-Water Research Institute.

Agorsah, E. K. (2004). Ethnoarcheological analysis of human functional dynamics in Volta basin in Ghana: before and after the Akosombo dam. New York, USA: Edwin Meller Press.

Allan, J. D. (1996). Stream ecology: structure and function of running waters. London, UK: Chapman and Hall.

Barnes, R. S. K. (1980). Coastal Lagoons (2 ${ }^{\text {nd }}$ ed.). London, UK: Cambridge University Press.

Carey, T. G. (1971). Hydrological survey of the Kafue floodplain. Fisheries Research Bulletin, 3, 9-12.

Clarke, K. R., \& Gorley, R. N. (2006). PRIMER v6: User Manual/Tutorial. PRIMER-E Plymouth.

Conde, D., Bonita, S., Aubruit, R., Leon, D., \& Pintos, W. (2007). Relative contribution of planktonic and benthic microalgae production in a eutrophic coastal lagoon of South America. Journal of Limnology, 78, 207-212. 
Dahlberg, M. D., \& Odum, E. P. (1970). Annual cycle of species occurrence, abundance and diversity in Georgia estuarine fish populations. American Midland Naturalist Journal, 83, 382-392.

Emmanuel, B. C., \& Onyema, I. C. (2007). The plankton and fishes of a tropical Creek in South Western Nigeria. Turkish Journal of Fisheries \& Aquatic Science, 7, 105-113.

Erondu, E. S., \& Chinda, A. C. (1991). Variations in the Physico-chemical features and phytoplankton of Calabar River at Aluu, Rivers State, Nigeria (Tech. Pap. No. 75). Nigeria: Nigerian Institute of Oceanography and Marine Research.

FAO. (2001). Dams, fish and fisheries, opportunities, challenges and conflict resolution. In G. Marmulla (Ed.), FAO Fisheries Tech. Pap. No. 419 (pp. 166). Rome, Italy: FAO.

Hess, L. W., Schlesinger, A. B., Hergenrader, G. L., Reetz, S. D., \& Lewis, H. S. (1982). The Missouri river study-ecological perspective. In L. W. Hess, G. L. Hergenrader, H. S. Lewis, S. D. Reetz, \& A. B. Schlesinger (Eds.), The middle Missouri river (pp. 287301). Nebraska, USA: Missouri river study group.

Hewett, S. W., \& Johnson, B. L. (1987). A generalized bioenergetics model for fish growth for microcomputers (Sea Grant Technical Report. WIS-SG-82-245). Madison, Wisconsin: University of Wisconsin.

Junk, W. J., Bayley, P. B., \& Sparks, R. E. (1989). The flood pulse concept in river-floodplain systems. In D. P. Dodge (Ed.), Proceedings of the international large river symposium (pp. 110-127). Canada: Canadian Special Publication of Fisheries and Aquatic Sciences.

Kolo, R. J., Ojutiku, R. O., \& Musulmi, D. T. (2010). Plankton communities of Tagwai Dam Minna, Nigeria. Canadian Journal of Fisheries \& Aquatic Science, 4, 1-7.

Lund, J. W. G., Kipling, C. D., \& le Cren, E. (1958). The inverted microscope method of estimating algal numbers and the statistical basis of estimations by counting. Hydrobiologia, 11, 143-170.

Mordukhai-Boltovskoi, P. D. (1979). The River Volga and its life. Monographs in Biology, 33, 473-479.

Needham, J. G., \& Needham, R. R. (1962). A guide to the study of freshwater biology. California, USA: Holden Day, Inc.

Ogamba, E. N., Chinda, A. C., Ekweozor, I. K. E., \& Onwuteaka, J. N. (2004). Water quality and phytoplankton distribution in Elechi Creek complex of the Niger Delta. Journal of Nigerian Environmental Society, 1, 121-130.
Petts, G. E. (1984). Impounded Rivers. Chichester, UK: John Willey and Sons.

Prowse, G. A., \& Talling, J. F. (1958). The seasonal growth and succession of plankton algae in the White Nile. Limnology \& Oceanography, 3, 222-38.

Rocha, O., Matsumura-Tundisi, T., Espindola. E. L. G., Roche, K. F., \& Rietzler, A. C. (1999). Ecological theory applied to reservoir zooplankton. In J. G. Tundisi, \& M. Straskraba (Eds.), Theoretical reservoir ecology and its applications (pp. 29-51). Leiden, Holland: Backhuys Publishers.

Rzoska, J., \& Talling, J. F. (1966). Plankton development in relation to hydrology and reservoir regime in the Blue Nile. Verhandlungen der Internationalen Vereinigung fur Theoretische und Angewandte Limnologie, 16, 716-718.

Rzoska, J. (1974). The Upper Nile Swamps, a tropical wetland study. Freshwater Biology, 4, 1-30.

Shannon, E. C., \& Weaver, W. (1963). The Mathematical Theory of Communication. Urbana, USA: University of Illinois Press.

Tundisi, J. G. (1993). Composition and abundance of zooplankton and size fractionation of the phytoplanktonic community in several reservoirs of Paranapanema River, Brazil. Brazilian Journal of Biology, 62, 525-545.

Viner, A. B. (1970). Hydrobiology of the Volta Lake, Ghana I. Stratification and circulation of water. Hydrobiologia, 35, 20-29.

Visser, S. A. (1970). The distribution of organic compounds in freshwater lakes and rivers. In S. A. Visser (Ed.), Kainji lakes studies (pp. 107-125). Nigeria: Ibadan University Press.

Wehr, I. D., \& Descy, J. P. (1998). Use of Phytoplankton in large river management. Journal of Phycology, 34, 741-749.

Welcomme, R. L. (1985). River fisheries (Tech. Pap. No. 345). Rome, Italy: FAO Fish.

Wetzel, R. G., \& Likens, G. E. (1990). Reservoir ecosystems: conclusions and speculations. In K. W. Thornton, B. L. Kimmel, \& F. E. Payne (Eds.), Reservoir limnology: ecological perspectives (pp. 227-239). New York, USA: Wiley-Interscience.

Williams, H. (1964). Possible relation between plankton and diatom species and water quality estimates. Eco$\log y, 45,809-823$.

Zabbey, N., Sikoki, F. D., \& Edoghotu, J. (2008). Plankton assemblages and environmental gradients in the middle reaches of the Imo river, Niger Delta, Nigeria. African Journal of Aquatic Science, 33, 241-248. 